I. M. Pistunov, Dr. Sc. (Tech.), Prof., orcid.org/0000-0002-9041-8368, I. A. Bielkina, Cand. Sc.(Econ.), orcid.org/0000-0002-0789-2545, O. Yu. Churikanova, Cand. Sc.(Econ.), orcid.org/0000-0001-5703-2271
National Mining University, Dnipro, Ukraine, e-mail: pistunovi@gmail.com; irinabelkina88@gmail.com; elenachurikanova@gmail.com

\title{
INTEGRATION OF STATISTICAL MODEL FOR OPTIMUM INVENTORY AND WILSON EOQ MODEL
}

Purpose. Development of method for determining the optimal stock of products, which would allow combining several models of optimal order quantity estimation, excluding errors of each composing model.

Methodology. The analytical model that allows averaging the estimation results obtained by means of statistical and Wilson models is designed. Optimization approach to the problem ensures uniqueness of obtained results and provides proper and unambiguous solution.

Findings. It is statistically substantiated and experimentally confirmed that the statistical and Wilson models, designed to determine the optimal order quantity provide far different results. The capacity of combining the results of these calculations in a single complex is examined.

Originality. For the first time the difference between the data obtained by means of Wilson and statistical models is defined. A formula of combining the results into a single package assuring unification of both approaches is developed.

Practical value. The optimal order supply for each product type on the criteria minimum of unsold goods storage costs or maximum of sale profit or minimum amount of unit storage can be defined having the following consumption parameters: overall demand statistics, net cost plus additional storage costs per unit of product, delivery and placing goods costs, stock capacity, the amount of stock remains, deficit matrix for each commodity type and sales profit per product type. Moreover, consideration of warehouse capacity allows determining the product that ensures maximum of sale profit. The method had been tested on real business data.

Keywords: inventory management, optimum order quantity, economic and mathematical model, missed profit, supply chain management, operational expenses

Introduction. Economic activity of an enterprise may involve concentration of major part of its financial resources in inventory holdings. Inaccurate demand appraisal can cause conservation of a firm's cash in the inventory balance as well as inefficient warehouse usage. Therefore, effective order planning is to become one of the most important issues for an operation manager. Optimal order quantity determination should be based on analysis of current order plan with taking into account other factors, such as: season, storage capacity, duration of delivery, and others. Effective order quantity plan enables enterprise to forecast the firm's financial indicators, to plan material and technical foundation development, to project costs with remote in time income and to build business relationships with customers and suppliers, banks and other parties. Thus, no investor, creditor or bank would loan the enterprise which cannot give a clear prediction of its financial condition for the period up to repayment.

Analysis of the recent research and publications. One of the most prominent series of studies on inventory management was drawn by Grzegorz Michalski and is dedicated to enterprise value-based order quantity. Michalski's research works are conducted from the position of assuring maximum of firm value. However, this

(C) Pistunov I. M., Bielkina I. A., Churikanova O.Yu., 2018 approach does not take into account lost advantage missed profit.

Another perspective approach is to combine the order management models with logistics approaches, routing methods, transportation schedules, dynamic distribution modeling and others. Comprehensive critical analysis of these works is given in the article [1].

Linking of sales or demand forecast with inventory management is described in the works [2,3]. These approaches foresee certain risks coherent with forecast accuracy.

In recent years, works pullulated dedicated to combining invest management and closed-loop supply approach [4] or environmental-protection measures [5]. Such works are relevant for the countries with strong environmental-protective socio-economical policy that Ukraine does not have at the moment.

Most of contemporary research works, even those, described above, and informational systems consider classical inventory management models, such as Wilson economic order quantity (EOQ) and production order quantity (POQ), described in a work by M. Muller.

Unsolved aspects of the problems. Theoretically, Wilson model allows minimizing order management costs; still the issue is to understand its proper realization. The model assumes indirect restrictions that limit its execution. Practically, there are certain difficulties concerning 
estimation of holding costs and ordering costs. Costs most likely are not equal for different goods and orders, thereby usage of average meanings does remote a researcher or operational manager from exact optimal order quantity.

Objectives of this article are to develop and test economic and mathematical model that enables calculation of the optimal stock of goods in warehouses by means of Wilson and statistical approaches combination.

Presentation of the main research. Raw data for the present research were provided by "UPK Invest Dnipro". Input data contain information about the inflow and the outflow of three commodities for the last 3 years. The goods flow is illustrated in Fig. 1 for better perception. Though some information, such as supplier, is a commercial secret the enterprise has revealed the prices of the goods and delivery costs.

Analysis of the graphs has shown periodical deficit of goods for more than 4 days. Those days are highlighted on the graphs and such situation for the firm engaged in import/export trade is unacceptable. Calculation results of the average period of delivery and the number of days of stock downtime are shown in Table 1. One practical solution to this problem is to place order at the moment when the firm runs out of stock. But there are certain restrictions, as the product is specific and the speed of delivery period in no less than a week. Therefore, it was considered more preferable to calculate the optimal delivery plan by combining statistical methods with Wilson method.

Analysis of data from Table 2 shows that the price of all commodities increases every year. This can be explained by internal economic situation of Ukraine, particularly, by rising prices of fuel and spare parts that are not the purpose of the study. The third product is supplied from neighboring countries, so it has the highest price.

To determine holding costs and ordering costs per kilo, a yearly averaged value of goods was estimated for 2013-2015. All data related are presented in Table 3. The table demonstrates that in the first year holding costs were higher than in the next. The decrease in the costs corresponds to a change in storage room that used to be smaller and equipped in a different way. Ordering cost is proportional to the change of prices of fuel and energy resources. Unit values in Table 3 are taken based on the fact that one bag weights $20 \mathrm{~kg}$.
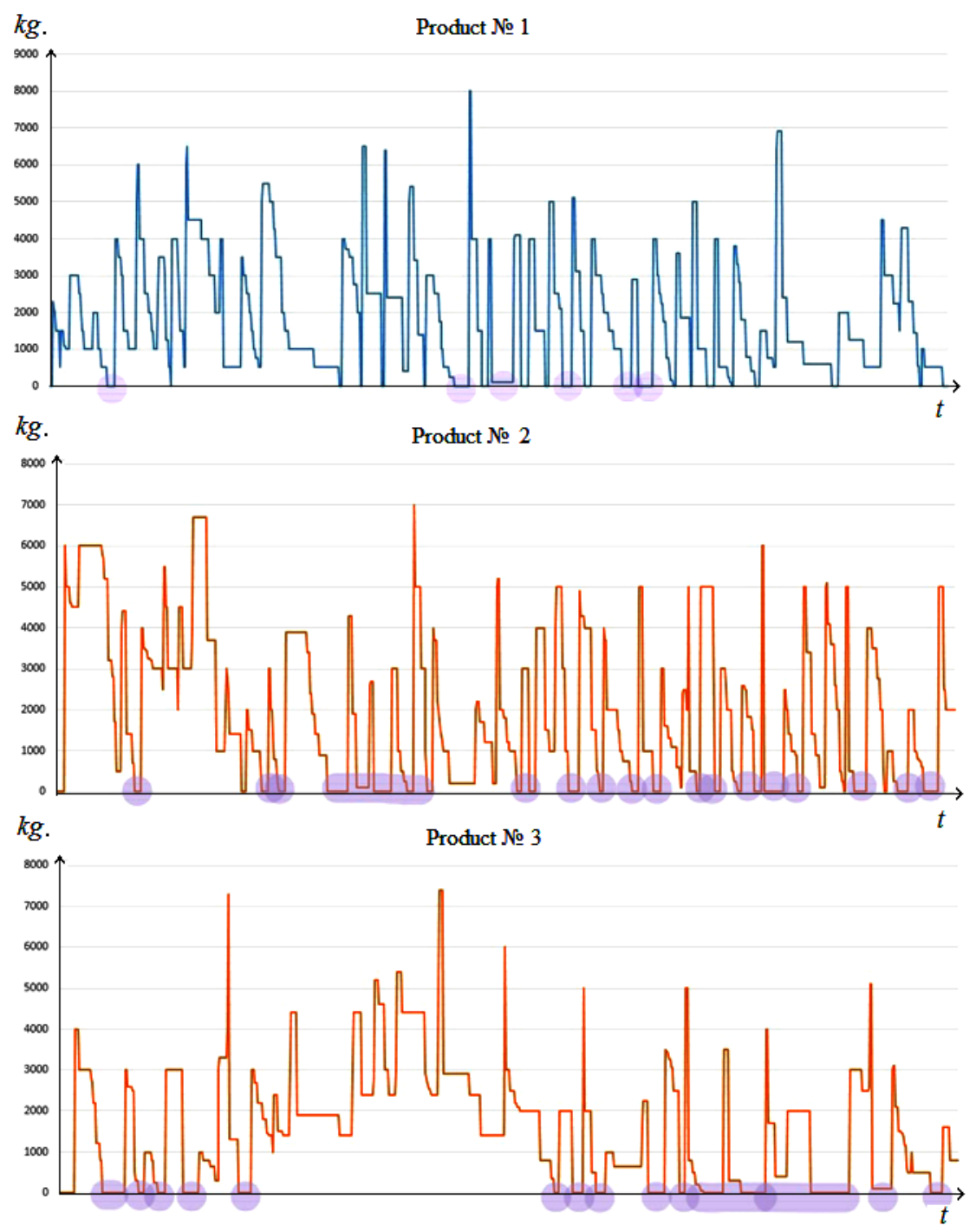

Fig. 1. Dynamics of stockholdings for 3 years 
Table 1 comes to quantity discounts and storage deficit. Assump-

Stock management indicators

\begin{tabular}{|l|c|c|c|}
\hline & $\begin{array}{c}\text { Product } \\
\text { No. 1 }\end{array}$ & $\begin{array}{c}\text { Product } \\
\text { No. 2 }\end{array}$ & $\begin{array}{c}\text { Product } \\
\text { No. 3 }\end{array}$ \\
\hline Total amount of deliveries & 37 & 40 & 30 \\
\hline Average delivery time, days & 24.1 & 24 & 30 \\
\hline $\begin{array}{l}\text { The total number of days of } \\
\text { downtime }\end{array}$ & 22 & 26 & 17 \\
\hline $\begin{array}{l}\text { The average number of days } \\
\text { of downtime }\end{array}$ & 5.8 & 8.6 & 13.6 \\
\hline
\end{tabular}

Table 2

Product price, UAH/kilo

\begin{tabular}{|c|c|c|c|}
\hline \multirow{2}{*}{ Year } & \multicolumn{3}{|c|}{ Product type } \\
\cline { 2 - 4 } & No. 1 & No. 2 & No. 3 \\
\cline { 2 - 4 } 2013 & 260.0 & 286.0 & 300.0 \\
\hline 2014 & 270.0 & 304.0 & 340.0 \\
\hline 2015 & 300.0 & 310.0 & 360.0 \\
\hline 2016 & 300.0 & 310.0 & 360.0 \\
\hline
\end{tabular}

Table 3

Holding and ordering costs, UAH

\begin{tabular}{|c|c|c|}
\hline \multirow{2}{*}{ Year } & $\begin{array}{c}\text { Holding costs per } \\
\text { year (for 20 kilos) }\end{array}$ & $\begin{array}{c}\text { Ordering costs } \\
\text { (for 20 kilos) }\end{array}$ \\
\cline { 2 - 3 } 2013 & 1.00 & 14.00 \\
\hline 2014 & 1.50 & 17.00 \\
\hline 2015 & 2.00 & 31.00 \\
\hline 2016 & 2.00 & 40.00 \\
\hline
\end{tabular}

Demand for goods was calculated as the sum of all deliveries to the warehouse for the year, excluding periods of downtime in demand during the first two years. Demand for the 2016 was not taken into account.

One bag contains 20 kilos of substance. In the warehouse bags are stored by 2 in several layers on a pallet. The capacity of warehouse is up to 18,000 kilos or 900 bags with the opportunity to freely move between rows.

Table 4 shows the annual growth of products demand that is linked to the ascend in warehouse capacity and the emergence of new customers.

Wilson EOQ Model. The classical Wilson EOQ Model determines order quantity that minimizes the total holding costs and ordering costs. The framework is limited when it

Table 4

Annual demand, kilo

\begin{tabular}{|c|c|c|c|}
\hline \multirow{2}{*}{ Year } & \multicolumn{3}{|c|}{ Product type } \\
\cline { 2 - 4 } & No. 1 & No. 2 & No. 3 \\
\cline { 2 - 4 } 2013 & 37800 & 39300 & 25980 \\
\hline 2014 & 49900 & 38900 & 23800 \\
\hline 2015 & 50100 & 65400 & 36800 \\
\hline
\end{tabular}

tions of the model: demand quantity for the period is known, order period is constant, unit shipment is instant. Optimal order quantity is estimated by the formula

$$
Q=\sqrt{\frac{2 C R}{P F}}=\sqrt{\frac{2 C R}{H}},
$$

where $Q$ is optimal order quantity; $C$ is fixed cost per order; $R$ is demand quantity; $P$ is purchase unit price; $F$ is interest rate; $H$ is annual holding cost per unit.

Statistical approach. Cumulative was build in order to distribute a whole range of possible values of random variable observations on the $d$ intervals. Interval's upper limit of a random variable is estimated as

$$
d_{\max }(i)=x_{\min }+\left(x_{\max }-x_{\min }\right) i / d,
$$

where $i$ is the number of interval $[1, d]$; xmax, xmin are the largest and the smallest values of a random variable in the sample, respectively. The upper limit of interval $i$ is also the lower limit ( $i 01)$ interval. The lower limit for the $1^{\text {st }}$ area is equal to $x_{\min }$, while the upper limit of the last interval is equal to $-x_{\max }$.

Tentatively, the number of intervals or bins can be defined as

$$
d_{o p}=\frac{x_{\max }-x_{\min }}{1+3.332 \ln N} .
$$

Grouped frequency distributions is given in Table 5, where $k_{i}$ is relative frequency; $C_{i}$ is cumulative frequency where $K_{i}$ is the number of hits in the interval; $N_{i}$ is the total number of deliveries to the warehouse of $i$-product (for $N_{1}=34, N_{2}=36, N_{3}=30$ ). The number of intervals or bins $d_{o p}=5$. Interval width is equal to 2000 kilos.

As shown in Table 5 the largest number of orders falls on the third interval (2001-4000). The cumulative frequency curves (Figs. 2, 3 and 4) were built based on the data from Table 5. The graphs also contain logarithmic trend equation; its coefficients are shown in Table 6.

According to the statistical approach, optimal order quantity can be determined with the formula

$$
q=R \cdot e^{\left(\frac{B}{A} \cdot \frac{H_{1}}{H_{1}+C}\right)},
$$

where $q$ is optimal order quantity; $R$ is demand; $A, B$ are coefficients of the equation; $H_{1}$ is storage cost per kilo of product; $C$ is the cost of order, delivery and placement of goods in stock.

The calculation results for each product according to statistical approach and to Wilson model are listed in Table 7.

The optimal amount of supply according to Wilson EOQ model is 316 bags of the first, 361 bags of the second and 271 bags for the third type of goods. According to the statistical approach, optimal order quantity should be increased by $196 \%$ for the first, $254 \%$ for the second and $43 \%$ for the third type of goods. Calculations were made providing 275 working days in a year.

Statistical and Wilson EOQ Models Integration. The optimal order quantity can be estimated using the methods of economic-mathematical modeling. Software 
Table 5

Grouped frequency of goods quantity order

\begin{tabular}{|c|c|c|c|c|c|c|c|c|c|c|}
\hline \multicolumn{2}{|c|}{ Interval limits } & \multicolumn{4}{|c|}{ Frequency $\left(K_{i}\right)$} & \multicolumn{3}{c|}{ Relative frequency $\left(k_{i}=K_{i} / N_{i}\right)$} & \multicolumn{3}{c|}{ Cumulative frequency $\left(C_{i}=k_{i-1}+k_{i}\right)$} \\
\hline Lower & Upper & $\begin{array}{c}\text { Product } \\
\text { No. 1 }\end{array}$ & $\begin{array}{c}\text { Product } \\
\text { No. 2 }\end{array}$ & $\begin{array}{c}\text { Product } \\
\text { No. 3 }\end{array}$ & $\begin{array}{c}\text { Product } \\
\text { No. 1 }\end{array}$ & $\begin{array}{c}\text { Product } \\
\text { No. 2 }\end{array}$ & $\begin{array}{c}\text { Product } \\
\text { No. 3 }\end{array}$ & $\begin{array}{c}\text { Product } \\
\text { No. 1 }\end{array}$ & $\begin{array}{c}\text { Product } \\
\text { No. 2 }\end{array}$ & $\begin{array}{c}\text { Product } \\
\text { No. 3 }\end{array}$ \\
\hline 0 & 1000 & 1 & 1 & 5 & 0.029 & 0.028 & 0.167 & 1 & 1 & 5 \\
\hline 1001 & 2000 & 3 & 5 & 5 & 0.088 & 0.139 & 0.167 & 4 & 6 & 10 \\
\hline 2001 & 4000 & 19 & 19 & 16 & 0.559 & 0.528 & 0.533 & 23 & 25 & 26 \\
\hline 4001 & 6000 & 7 & 12 & 4 & 0.206 & 0.333 & 0.133 & 30 & 37 & 30 \\
\hline 6001 & 8000 & 4 & 1 & 0 & 0.118 & 0.028 & 0.000 & 34 & 38 & 30 \\
\hline
\end{tabular}

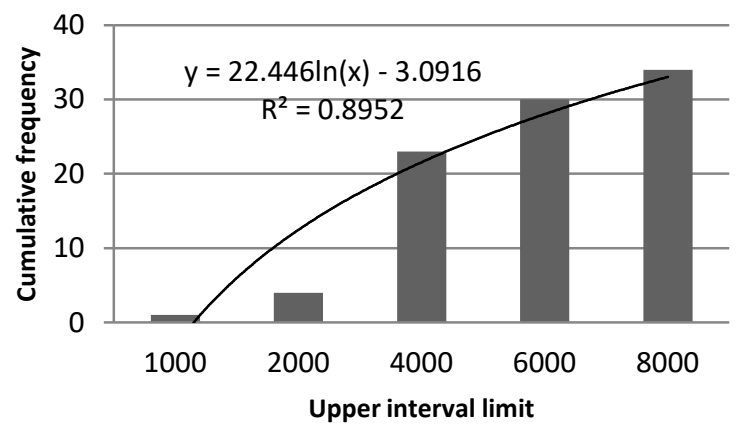

Fig. 2. Cumulative curve for product No. 1

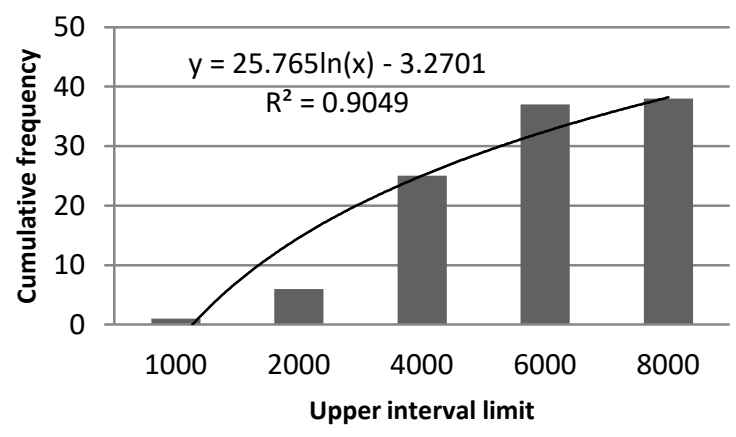

Fig. 3. Cumulative curve for product No. 2

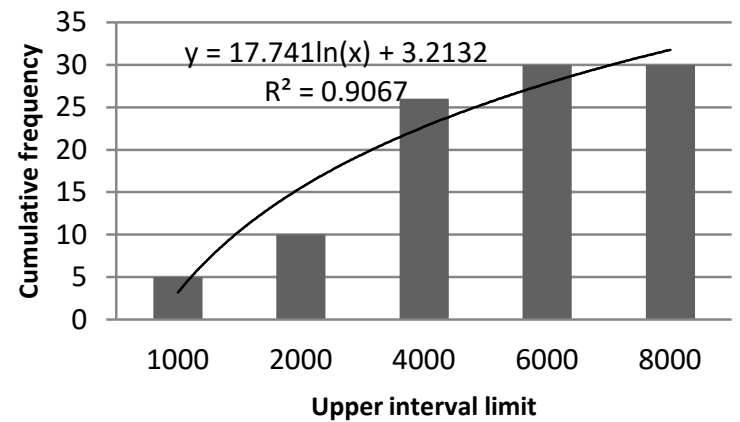

Fig. 4. Cumulative curve for product No. 3

package MS Office Excel and its Solver add-on were used to implement set task for "UPK Invest Dnipro".

Optimization problem will be set as follows
Table 6

Equation logarithmic function coefficients

\begin{tabular}{|c|c|c|c|}
\hline \multirow{2}{*}{ Coefficient } & \multicolumn{3}{|c|}{ Type of goods } \\
\cline { 2 - 4 } & No. 1 & No.2 & No. 3 \\
\hline A & 22.4 & 25.8 & 17.7 \\
\hline B & -3.1 & -3.3 & 3.2 \\
\hline
\end{tabular}

Table 7

The optimal order quantity estimation results

\begin{tabular}{|l|c|c|c|}
\hline \multirow{2}{*}{ Ratio } & \multicolumn{3}{c|}{ Type of goods } \\
\cline { 2 - 4 } & No. 1 & No. 2 & No. 3 \\
\hline $\begin{array}{l}\text { Optimal order quantity according } \\
\text { to the statistical method, kilo }\end{array}$ & 936 & 1281 & 389 \\
\hline $\begin{array}{l}\text { Optimal order quantity according } \\
\text { to Wilson EOQ model, kilo }\end{array}$ & 316 & 361 & 271 \\
\hline $\begin{array}{l}\text { Optimal order quantity according } \\
\text { to the integrated model, kilo }\end{array}$ & 368 & 472 & 323 \\
\hline
\end{tabular}

$$
F=\frac{\sum_{i=1}^{3}\left(\left|q_{o p t C}-q_{o p t W}\right|\right) * X_{i}}{\sum_{i=1}^{3}\left(P_{3} * q_{i}\right) * X_{i}} \rightarrow \min
$$

Constrains

$$
\left\{\begin{array}{l}
q_{\text {iopt } W} \leq q_{i} \leq q_{\text {iopt } C} \\
q_{i} \geq 0 \\
\sum_{i=1}^{3} q_{i}+L \leq W
\end{array}\right.
$$

where $W$ is warehouse capacity; $L$ stands for remains of stock; $q_{o p t} C$ is the optimal order quantity according to the statistical method; $q_{\text {opt }} W$ is the optimal order quantity according to Wilson EOQ model; $X_{i}$ is the deficit matrix of product $i(1-$ yes, $0-$ no) (matrix size $1 \times 3)$; $P_{i}$ is profit on product $i$ sales; $q_{i}$ is the optimal order quantity for product $i$.

To estimate the elements of the deficit matrix condition "if" was used to determine the need automatically. For example, if the remains of the composition are less 
than 1500 kilos or 25 bags, the order is obligatory $\left(X_{i}=1\right)$. If remains exceed 1500 kilos, the order is not required $\left(X_{i}=0\right)$. Provided that the calculation of order requirement will be driven automatically, by means of MS Excel order requirement is calculated as follows: $=\operatorname{IF}\left(X_{i}<\right.$ $<150 ; 1 ; 0)$. To implement this optimization model, it was decided to use the formula "if" because of certain difficulties in MS Excel usage in practice, so the model for further calculations will be as follows

$$
\begin{gathered}
F=\frac{G}{I} \rightarrow \min ; \\
G=\sum_{i=1}^{3} \begin{cases}\left|q_{\text {opt } C i}-q_{\text {opt } W i}\right|, & \text { if } X_{i}=1 \\
0, & \text { if } X_{i}=0\end{cases} \\
I=\sum_{i=1}^{3} \begin{cases}\left(P_{3} * q_{i}\right), & \text { if } X_{i}=1 \\
0, & \text { if } X_{i}=0\end{cases}
\end{gathered}
$$

In the process of model modernization correct optimal order quantity was received (the results are listed in Table 7). The calculations were made under the condition that the remaining goods in stock are equal to 31, 24 and 41 sacks for product type $1-3$ relatively.

The cost of order, delivery and placement of goods in stock for products No. 1-3 are 634, 945 and 542 UAH. respectively; potential profit is 94330, 145426 and 97122 UAH. Obtained results fully meet the requirements of the enterprise, and therefore the usage of the integrated model is effective.

Conclusion. The aim of the development was to create economic and mathematical model to calculate the optimum order volume for the company "UPK Invest Dnipro".

Optimal order quantity was estimated for "Invest Yupk Dnepr" using two approaches: the model of Wilson and statistical method. However, neither of these methods is suitable as the primary model for calculating the optimal level of order through certain specifics of the company. Thus, it was proposed to combine those two models.

To calculate the lower limit of the optimum order volume Wilson's model was used and the statistical method was applied to determine the upper limit. The main advantage of the proposed model is the possibility to choose product to order (matrix needed) and composition taking into account.

\section{References.}

1. Andersson, H., Hoff, A., Christiansen, M., Gei Hasle, G. and Løkketangen, A., 2010. Industrial aspects and literature survey: Combined inventory management and routing. Computers and Operations Research [online], 37(9), pp. 1515-1536. Available at: <http://www.sciencedirect.com/science/article/pii/S0305054809002962> [Accessed 21 April 2017].

2. Kot, S., Grondys, K. and Szopa, R., 2011. Theory of inventory management based on demand forecasting. Polish journal of management studies [pdf], 3, pp. 147-155. Available at: <http://oaji.net/articles/2014/13841415172623.pdf $>$ [Accessed 11 July 2017].
3. Pistunov, I. M. and Bielkina, I.A., 2010. Forecast of seam-les pipes export in 2010. Economika: problem teorii $i$ praktyky [pdf], 261(2), pp. 414-418. Available at: $<$ http://pistunovi.inf.ua/Bel.pdf [Accessed 7 May 2017]. 4. Dekker, R., Fleischmann, M., Inderfurth, K. and van Wassenhove, L. N., eds, 2013. Reverse logistics: quantitative models for closed-loop supply chains, Springer Science \& Business Media.

5. Kim, M. and Chai, S., 2017. Implementing Environmental Practices for Accomplishing Sustainable Green Supply Chain Management. Sustainability, 9(7), p. 1192.

\section{Об'єднання статистичної моделі оптимальних запасів і моделі Уілсона}

\section{І. М. Пістунов, І. А. Бєлкіна, О. Ю. Чуріканова}

Державний вищий навчальний заклад „Національний гірничий університет“, м. Дніпро, Україна, e-mail: pistunovi@ gmail.com; irinabelkina88@gmail.com; elenachurikanova@ gmail.com

Мета. Розробка методики визначення оптимального запасу товарів на складі, яка б дозволяла об'єднати декілька моделей розрахунку оптимального запасу товарів на складах, з унеможливленням похибок, що вносять різні моделі оптимізації

Методика. Розроблена аналітична модель, що дозволяє усереднити результати визначення оптимального запасу товарів на складах за статистичною моделлю й моделлю Вільсона. Оптимізаційний підхід до вирішення проблеми забезпечив унікальність отриманих результатів і дав гарантовано вірне та єдине рішення.

Результати. Статистично обгрунтовано та експериментально підтверджено, що статистична модель і модель Вільсона, розроблені для визначення оптимального запасу товарів на складах, дають результати, що відрізняється в декілька разів. Показана можливість об'єднання результатів цих розрахунків у єдиний комплекс.

Наукова новизна. Уперше визначена різниця поміж результатами розрахунків оптимального запасу товарів на складах за моделями Вільсона та статистичною моделлю. Розроблена формула об'єднання цих результатів у єдиний комплекс, що забезпечує уніфікацію обох підходів.

Практична значимість. Якщо мати такі параметри споживання продукції зі складу, як: статистика загального попиту, собівартість, додаткові витрати на зберігання одиниці продукту, витрати на доставку й розміщення товару на складі, об’єм складу, залишки на складі, матриця необхідності кожного товару, прибуток від реалізації, тоді можливо точно визначити оптимальний обсяг запасу товарів на складі для кожної з позицій за критеріями мінімуму втрат від зберігання непридбаних товарів, максимуму прибутку від реалізації товарів, а також мінімуму обсягу запасу в одиницях зберігання. Причому, урахування максимального обсягу складу дозволяє визначити такий обсяг товарів, щоб прибу- 
ток від їх реалізації був максимальним. Розроблена методика була перевірена на реальних даних комерційного підприємства.

Ключові слова: управління запасами, оптимальний розмір замовлення, економіко-математична модель, втрачений прибуток, управління поставками, операційні витрати

\section{Объединение статистической модели оптимальных запасов и модели Уилсона}

\section{И. Н. Пистунов, И. А. Белкина, Е. Ю. Чуриканова}

Государственное высшее учебное заведение „Национальный горный университет“, г. Днепр, Украина, e-mail: pistunovi@gmail.com; irinabelkina88@gmail.com; elenachurikanova@gmail.com

Цель. Разработка методики определения оптимального запаса товаров на складе, позволяющая объединить несколько моделей расчета оптимального запаса товаров на складах, с нивелированием ошибок, которые вносят различные модели оптимизации

Методика. Разработана аналитическая модель, которая позволяет усреднить результаты определения оптимального запаса товаров на складах по статистической модели и модели Вильсона. Оптимизационный подход к решению проблемы обеспечил уникальность полученных результатов и дал гарантированно верное и единственное решение.

Результаты. Статистически обосновано и экспериментально подтверждено, что статистическая модель и модель Вильсона, разработанные для определения оптимального запаса товаров на складах, дают результаты, отличающиеся в несколько раз. Показана возможность объединения результатов этих расчетов в единый комплекс.

Научная новизна. Впервые определена разница между данными, полученными в результате расчета оптимального запаса товаров на складах по модели Уилсона и статистической моделью. Разработана формула объединения этих результатов в единый комплекс, обеспечивающий унификацию обоих подходов.

Практическая значимость. Если иметь такие параметры потребления продукции со склада, как: статистика общего спроса, себестоимость, дополнительные расходы на хранение единицы продукта, расходы на доставку и размещение товара на складе, объем склада, остатки на складе, матрица потребностей каждого товара, прибыль от реализации каждого товара, тогда возможно точно определить оптимальный объем запаса товаров на складе для каждой из позиций по критериям минимума потерь от хранения нереализованных товаров, максимума прибыли от реализации товаров, а также минимума объема запаса в единицах хранения. Причем, учет максимального объема склада позволяет определить такой объем товаров, чтобы прибыль от их реализации была максимальной. Разработанная методика была проверена на реальных данных коммерческого предприятия.

Ключевые слова: управление запасами, оптимальный размер заказа, экономико-математическая модель, утраченная прибыль, управление поставками, операционные расходы

Рекомендовано до публікації докт. екон. наук Г.М.Пилипенком. Дата надходження рукопису 18.01.17. 